\title{
Contribuições do pensamento bakhtiniano à análise semiolinguística do discurso
}

Carolina Leal Pires

\section{Resumo:}

O presente ensaio busca identificar possíveis influências do pensamento de Mikhail Bakhtin na Semiolinguística, teoria fundada por Patrick Charaudeau em 1983, cotejando algumas ideias encontradas em obras de ambos os autores.

\section{Palavras Chave:}

Semiolinguística, discurso, dialogismo.

\begin{abstract}
:
The present essay try to identify which are the possibles influences of the thought of Mikhail Bakhtin in the Semiolinguistic, a teory founded by Patrick Charaudeau in 1983, compared some ideas that are in the job of both authors.
\end{abstract}

\section{Keywords:}

Semiolinguistic, discourse, dialogism.

Patrick Charaudeau, na introdução do livro Langage et discours (1983), adverte sobre a ausência de referências explícitas às ideias de outros autores que contribuíram para a construção da sua Teoria Semiolinguística:

(...) toda teoria, como toda palavra, se define em relação a outras teorias, a outras palavras; (...) Não conseguindo estabelecer uma diferenciação entre nossa palavra e as múltiplas palavras de outros, não citaremos, ao longo de nosso percurso, nem as teorias precisas, nem os autores por elas responsáveis por tudo o que ficou ecoando em nosso pensamento até ser cristalizado em palavras, palavras cuja paternidade não assumimos totalmente, mas somente em parte (CHARAUDEAU apud MACHADO, 2005: 19-20).

Nesse breve trecho, já podemos notar a influência do pensamento bakhtiniano em Charaudeau (1). O próprio autor francês, ao proferir palestra no Curso de Pós-Graduação em Letras da Universidade Federal de Minas Gerais, admitiu tal inspiração. Lembramos, pois, como a palavra do outro é definida por Bakhtin, em Estética da Criação Verbal (2003: 379):

[...] qualquer palavra de qualquer outra pessoa, dita ou escrita na minha própria língua ou em qualquer outra língua, ou seja, é qualquer outra palavra não minha. Neste sentido, todas as palavras (enunciados, produções de discurso e literárias), além das minhas próprias, são palavras do outro. Eu vivo em um mundo de palavras do outro. [grifo do autor] 
Charaudeau apropria-se da ideia de Bakhtin de que a nossa palavra está sempre em relação dialógica com a palavra do outro. Para ambos os autores, as palavras não deixam de pertencer ao indivíduo, ele não apenas as repete, não se trata do sujeito assujeitado dos primórdios da $\mathrm{AD}$ francesa; mas também as palavras não são suas integralmente: elas estão divididas entre as suas próprias e as do outro, confundindo-se, numa "tensa luta dialógica" (BAKHTIN, 2003: 379-380) ao entrar em contato com outros discursos, com outros pontos de vista, opiniões, teorias, crenças.

A influência de Bakhtin em Charaudeau, contudo, não se esgota aí. Podemos encontrá-las ainda em alguns fundamentos da Análise Semiolinguística do Discurso( ), como por exemplo, quando o autor francês fala sobre o processo de semiotização do mundo( ).

Segundo Charaudeau, os sentidos estão relacionados não só a formas linguísticas como também a outros sistemas semióticos como o icônico, o gestual etc., sendo que a semiotização do mundo constituída pelos processos de transformação, transação e interpretação - acontece sempre nas situações de trocas sociais, através da atividade linguageira do homem.

O homem, ao nomear os seres, ao qualificar estes seres, ao narrar suas ações, ao argumentar e avaliar estas ações e seus motivos está entrando em contato com o mundo, está transformando o mundo a significar em mundo significado (CHARAUDEAU, 2006: 41). Contudo, este contato não se dá de forma passiva, mas ativa. Podemos, então, nos remeter à ideia bakhtiniana do dialogismo entre homem e objeto. Bakhtin (1993, p. 33) afirma que só o fato de começar a falar sobre este mundo já significa que o indivíduo tomou uma atitude sobre o mundo, sobre o objeto "não uma atitude indiferente, mas uma atitude efetiva e interessada".

Mas, quando transformamos o mundo a significar em mundo significado também estamos em relação, em transação com o outro, negociando sentidos. Pensamos: quem é este outro? Qual a sua posição social, seu estado psicológico, suas aptidões, seus interesses? Que efeito pretendemos produzir nele? Que tipo de relação queremos implantar com este outro? Segundo Charaudeau, é este processo de transação que comanda o processo de transformação. Diz o autor, retomando a questão da intersubjetividade tal qual postula Bakhtin( ):

A finalidade do homem, ao falar, não é a de recortar, descrever, estruturar o mundo; ele fala, em princípio, para se colocar em relação com o outro, porque disso depende a própria existência, visto que a consciência de si passa pela tomada de consciência da existência do outro, pela assimilação do outro e ao mesmo tempo pela diferenciação com relação ao outro. A linguagem nasce, vive e morre na intersubjetividade. É falando com o outro - isto é, falando o outro e se falando a si mesmo - que comenta o mundo, ou seja, descreve e estrutura o mundo (CHARAUDEAU, 2006: 42).

Ainda de acordo com Charaudeau, a semiotização do mundo não se encerra no mundo significado: há também o processo de interpretação, onde o mundo significado passa a ser um mundo interpretado. $\mathrm{O}$ outro, numa relação de transação com seu interlocutor, irá interpretar este mundo significado, segundo seus próprios parâmetros. Podemos, portanto, novamente nos reportar a Bakhtin (2003: 377-378), quando este fala que compreensão do texto pelo interlocutor não é análoga à do locutor, pois o interlocutor confere novos sentidos ao texto, completando-o e avaliando-o a partir de "sua visão de mundo já formada, de seu ponto de vista, de suas posições".

Na Semiolinguística também os sentidos do ato comunicativo( ) são construídos pela troca entre a 
instância de produção e de recepção, troca esta mediada pelo texto( ). Vistos por uma relação de intencionalidade, estes sentidos não são necessariamente correspondentes. Deve-se falar, portanto, em sentidos visados pela instância de produção e sentidos produzidos pela instância de recepção, sendo que "a relação entre os efeitos visados e os efeitos produzidos é bastante frouxa, muitas vezes retardada, não raro inesperada, ou mesmo contraditória" (CHARAUDEAU, 2006: 61). Os textos, da mesma forma, "apenas" portam efeitos de sentidos possíveis, sendo sua análise, portanto, uma busca dos "possíveis interpretativos":

A distinção que propomos, entre os três lugares de construção do sentido, permite explicar a informação [Charaudeau aqui está se referindo especificamente ao discurso jornalístico] como algo que não corresponde apenas à intenção do produtor, nem apenas à do receptor, mas como resultado de uma co-intencionalidade que compreende os efeitos visados, os efeitos possíveis, e os efeitos produzidos. Esses três lugares se definem, portanto, cada um em relação aos demais como num jogo de espelhos em que as imagens incidem umas sobre as outras (CHARAUDEAU, 2006: 28).

Bakhtin também vai tocar na questão da intencionalidade quando fala da conclusibilidade do enunciado. Segundo o autor, para que possa haver a possibilidade de resposta do interlocutor, o enunciado é percebido como inteiro, acabado, como se o falante dissesse ou escrevesse "tudo o que quis dizer em dado momento ou sob dadas condições" (BAKHTIN, 2003: 280). Reconhecer, então, a vontade discursiva do falante é um dos elementos que permite o enunciado ser percebido como concluído:

Em cada enunciado - da réplica monovocal do cotidiano às grandes e complexas obras de ciência ou de literatura - abrangemos, interpretamos, sentimos a intenção discursiva de discurso ou a vontade discursiva do falante, que determina o todo do enunciado, o seu volume e as suas fronteiras. Imaginamos o que o falante quer dizer, e com essa ideia verbalizada, essa vontade verbalizada (como a entendemos) é que medimos a conclusibilidade do enunciado (BAKHTIN, 2003: 281). [grifos do autor]

Assim, para Bakhtin, o papel do outro na construção do enunciado é fundamental. Visando permitir a compreensão ativa responsiva, o locutor, ao construir o enunciado, procura antecipar a resposta do seu interlocutor, o que influencia direta e ativamente a construção deste enunciado:

Ao falar, sempre levo em conta o fundo aperceptível da percepção do meu discurso pelo destinatário: até que ponto ele está a par da situação, dispõe de conhecimentos especiais de um dado campo cultural da comunicação; levo em conta as suas concepções e convicções, os seus preconceitos (do meu ponto de vista), as suas simpatias e antipatias - tudo isso irá determinar a ativa compreensão responsiva do meu enunciado por ele (BAKHTIN, 2003: 302).

Todo enunciado, então, é sempre direcionado para alguém e é construído em função dessas respostas. O locutor usa a língua para uma necessidade concreta de enunciação, dirigindo a palavra a um interlocutor - real ou potencial -, ambos socialmente organizados. Dessa forma, a palavra varia se os interlocutores pertencem ou não ao mesmo grupo social, se existe hierarquia social entre eles, se estão em uma relação de proximidade, etc.:

Essa orientação da palavra em função do interlocutor tem uma importância muito grande. $\mathrm{Na}$ realidade, toda palavra comporta duas faces. Ela é determinada tanto pelo fato de que 
procede de alguém, como pelo fato de que se dirige para alguém. Ela constitui justamente o produto da interação do locutor e do ouvinte. (BAKHTIN, 2006: 117) [grifos do autor]

Portanto, se a palavra é produto da interação entre os interlocutores, o seu sentido não está nas estruturas linguísticas e sim na enunciação. Assim, é o contexto desta interação - tanto o meio social mais amplo quanto a situação mais imediata - que será determinante na construção do sentido do enunciado. Por isso que, como afirma Bakhtin(2006: 72), para se "observar o fenômeno da linguagem, é preciso situar os sujeitos - emissor e receptor do som -, bem como o próprio som, no meio social".

O meio social também é questão central para a Semiolinguística. Ao formular o conceito de "contrato de comunicação", Charaudeau corrobora Bakhtin ao dizer que os discursos estão intrinsicamente relacionados à situação social em que surgem e circulam.

De acordo com Charaudeau, na troca comunicativa, a instância de produção possui um projeto de fala, ou seja, um objetivo de comunicação que tem em vista a sua instância de recepção. Para alcançar este objetivo, a instância de produção utiliza-se de estratégias discursivas (o espaço das escolhas), que são "margens de manobras" permitidas pelo contrato de comunicação (o espaço das restrições da situação de interação).

Estas restrições dizem respeito, por exemplo, à identidade dos interlocutores (quem fala com quem? Qual seu status, sua idade, seu sexo? Existe relação hierárquica? Qual a proximidade afetiva entre os parceiros?); ao ambiente físico e tecnológico utilizados na comunicação; ao universo discurso tematizado; aos saberes compartilhados entre os interlocutores; etc. (CHARAUDEAU, 2002: 303-304).

Do então já exposto, podemos observar que alguns fundamentos da Semiolinguística de Charaudeau estão apoiados na concepção dialógica da linguagem de Bakhtin. Para ambos, locutor e interlocutor (ou falante e ouvinte, emissor e receptor, autor e leitor etc.) estão sempre em interação, participando ativamente da construção do sentido. Sendo a linguagem constitutivamente dialógica, o interlocutor não é visto mais como passivo no processo de comunicação, já que ele compreende responsivamente o enunciado( ).

Contudo, se hoje várias teorias passaram a considerar o papel ativo do outro, do interlocutor, no processo comunicativo, muito se deve às ideias inovadoras de Bakhtin, que surgiram em contraponto às "duas orientações do pensamento filosófico-linguístico" dominantes até então nos estudos sobre a linguagem: o subjetivismo idealista, representado por Humboldt e o objetivismo abstrato, representado por Saussure.

Para Bakhtin, tanto a primeira concepção (que tinha a língua como uma atividade mental, cuja fonte era o psiquismo individual) quanto a segunda (onde a língua, sistema de regras estável e imutável, era fato social externo à consciência dos falantes) deixavam de conceber a linguagem em sua totalidade ao desprezarem a fala (situação concreta de enunciação) como manifestação individual, mas de natureza imanentemente social: "A língua vive e evolui historicamente na comunicação verbal concreta, não no sistema linguístico abstrato das formas da língua nem no psiquismo individual dos falantes" (BAKHTIN, 2006: 128).

De acordo com o autor, apesar do subjetivismo idealista considerar a função comunicativa da 
linguagem, esta era subestimada, colocada em segundo plano:

Promovia-se ao primeiro plano a função da formação do pensamento, independente da comunicação. [...] A linguagem é considerada do ponto de vista do falante, como que de um falante sem a relação necessária com outros participantes da comunicação discursiva. Se era levado em conta o papel do outro, era apenas como papel de ouvinte que apenas compreende passivamente o falante (BAKHTIN, 2006: 270) [grifos do autor].

O objetivismo abstrato, segundo Bakhtin, também trazia uma ideia deturpada do processo de comunicação. As concepções de falante e ouvinte, presentes em Saussure, sugeriam um esquema comunicativo formado por um emissor ativo e um receptor passivo, no qual o papel do outro "era enfraquecido":

Não se pode dizer que esses esquemas sejam falsos e que não correspondam a determinados momentos da realidade; contudo, quando passam ao objetivo real da comunicação discursiva eles se transformam em ficção científica. Neste caso, o ouvinte, ao perceber e compreender o significado (linguístico) do discurso, ocupa simultaneamente em relação a ele uma ativa posição responsiva: concorda ou discorda dele (total ou parcialmente), completa-o, aplica-o, prepara-se para usá-lo etc. [...] Toda compreensão é prenhe de resposta, e nessa ou naquela forma a gera obrigatoriamente: o ouvinte se torna falante (BAKHTIN, 2006: 271).

Achamos importante recuperar toda esta crítica que Bakhtin fez ao subjetivismo idealista e ao objetivismo abstrato, para entender que Charaudeau, ao adotar uma abordagem comunicativa do discurso, vai afastar-se dessas concepções de Humboldt e Saussure, aproximando-se do dialogismo de Bakhtin. Então, apesar da Semiolinguística manter termos como "receptor" e "destinatário", por exemplo, estes não devem ser vistos como sujeitos passivos do ato de comunicação.

Charaudeau (2006, p. 72), inclusive, é contundente ao frisar que todo ato de comunicação põe em relação as suas instâncias de produção e de recepção, mas não de "um ponto de vista ingênuo". O autor, então, também irá criticar as primeiras teorias da informação, como a do modelo matemático de Shannon, que, por sua vez, inspirou o modelo de comunicação de Jakobson, ao afirmar que nestes modelos:

a comunicação [é] como um circuito fechado entre emissão e recepção, instaurando uma relação simétrica entre a atividade do emissor, cuja única função seria "codificar" a mensagem, e a do receptor, cuja função seria "decodificar" essa mesma mensagem (CHARAUDEAU, 2006: 35).

Na Análise Semiolinguística do Discurso, o ato comunicativo não é visto como homogêneo, unilateral, como uma simples transmissão de sinais ou mensagens, mas como um processo permeado pela "intersubjetividade constitutiva das trocas humanas". Assim, o interlocutor passa a desempenhar um papel fundamental na construção do sentido, como em Bakhtin. Esta superação dos primeiros modelos de comunicação, que mantinham a passividade do interlocutor, talvez tenha sido a maior contribuição bakhtiniana à Análise Semiolinguística do Discurso. 


\section{Bibliografia:}

BAKHTIN, Mikhail. Para uma filosofia do ato. Mimeo do original da edição americana: Toward a Philosophy of the Act. Trad. de Carlos A. Faraco e Cristóvão Tezza. Austin: University of Texas Press, 1993.

BAKHTIN, Mikhail. Estética da Criação Verbal. São Paulo: Martins Fontes, 2003.

BAKHTIN, Mikhail. Marxismo e Filosofia da Linguagem. São Paulo: Hucitec, 2006.

CHARAUDEAU, Patrick. "A communicative conception of discourse". Discourse Studies, Londres, v. 4, n. 3, 2002, p. 301-318. Disponível em: http://dis.sagepub.com/cgi/content/abstract/4/3/301. Acesso em: 02 set. 2008.

CHARAUDEAU, Patrick. Prefácio. In: Maria Pauliukonis; Sigrid Gavazzi (Orgs). Texto e Discurso: mídia, literatura e ensino. Rio de Janeiro: Lucerna, 2003, p. 7-8.

CHARAUDEAU, Patrick. Discurso das mídias. São Paulo: Contexto, 2006.

MACHADO, Ida. Algumas considerações sobre a Teoria Semiolinguística de Patrick Charaudeau. In: Ida Machado; João Santos; William Menezes (Orgs.) Movimentos de um percurso em Análise do Discurso Belo Horizonte: NAD/FALE/UFMG, 2005, p.19-32.

\section{Notas:}

(1) Trabalho apresentado em comunicação oral no XXII Jornada Nacional de Estudos Linguísticos do GELNE.

(2) Outras teorias - como a dos Atos de Fala, de Austin e Searle, a das Implicaturas Conversacionais, de Grice, a da Enunciação, de Benveniste, a da Competência Comunicativa, de Hymes - também permeiam a Semiolinguística, porém, não será objetivo deste trabalho abordálas.

(3) Sabemos que várias foram as contribuições de Bakhtin para os estudos sobre a linguagem em geral. Muitos conceitos da Pragmática, da Análise do Discurso, da Sociolinguística, dos Estudos Literários, etc. foram "abalados" com a descoberta e difusão da obra bakhtiniana pelo mundo. Mas como Charaudeau não explicita as fontes teóricas que sustentam a Semiolinguística, nos propomos apenas a encontrar elos entre as suas ideias e as de Bakhtin, a trazer à tona esse possível diálogo entre as duas teorias sem, contudo, ter a pretensão de esgotar as discussões sobre as questões aqui levantadas.

(4) Segundo Bakhtin (1993, 2003), o indivíduo se constitui para si e para seu outro e constitui seu outro (o eu-para-mim, o eu-para-o-outro e o outro-para-mim) numa relação de alteridade com este outro.

(5) Segundo Charaudeau, todo ato de linguagem, por ser um fenômeno social, coloca os indivíduos em relação uns com os outros - se constituindo em um ato de comunicação.

(6) Como Charaudeau (2006: 73) analisa a mídia, ele fala em instância, pois esta é "uma entidade 
compósita que compreende vários tipos de atores". Também na mídia, as instâncias de produção e de recepção não se encontram face a face, o que faz com que o texto seja um lugar privilegiado desta interação.

(7) Toda palavra, todo enunciado adquire uma "potência de sentido" no diálogo, que permite aos interlocutores uma resposta tanto aos enunciados precedentes quanto aos enunciados subsequentes.

\section{Mini Currículo :}

Carolina Leal Pires é mestre em Linguística pela UFPE. 